\title{
Pedagogiczne aspekty czasu wolnego
}

Powyższy temat przyświecał obradom międzynarodowej konferencji zorganizowanej w Żarach, w dniach 23-25 marca 2007 r., przez Łużycką Wyższą Szkołę Humanistyczną pod honorowym patronatem Burmistrza Żar, Romana Pogorzelca. Współorganizatorami konferencji był także Urząd Miejski w Żarach, miejscowy Oddział PTTK i Kuratorium Oświaty w Gorzowie Wielkopolskim. Uczestniczyli w niej licznie zarówno teoretycy, jak i praktycy edukacji z różnych krajowych ośrodków naukowych i placówek oświatowych, również goście ze Słowacji i Niemiec ${ }^{2}$.

W gronie uczestników konferencji znaleźli się także przedstawiciele polskiego środowiska historyków wychowania: prof. Krzysztof Jakubiak z Uniwersytetu Kazimierza Wielkiego w Bydgoszczy, prof. Adam Winiarz z Uniwersytetu im. M. Curii-Skłodowskiej w Lublinie, dr Jan Ryś i dr Ryszard Ślęczka z Akademii Pedagogicznej im. Komisji Edukacji Narodowej w Krakowie oraz prof. Wiesław Jamrożek reprezentujący Uniwersytet im. Adama Mickiewicza w Poznaniu i zarazem Łużycką Wyższą Szkołę Humanistyczną.

Konferencja została zainaugurowana w uroczystej Sali Sesyjnej Miasta Żary. Tutaj odbyły się obrady plenarne, którym przewodniczyła prof. Uniwersytetu Zielonogórskiego - Pola Kuleczka. W tej części obrad z referatem na temat problematyki czasu wolnego w dziejach europejskiej i polskiej myśli pedagogicznej wystąpił wspomniany prof. Adam Winiarz.

W godzinach popołudniowych pierwszego dnia konferencji obrady toczyły się w pięciu sekcjach wokół następujących zagadnień:

- czas wolny w zagrożonych i szczególnych środowiskach społecznych,

- humanistyczne wymiary czasu wolnego,

- czas wolny dzieci i młodzieży szkolnej i akademickiej,

- biomedyczne, ergonomiczne i medialne wymiary czasu wolnego,

- rodzina wobec czasu wolnego; czas wolny a turystyka.

Drugi i trzeci dzień konferencji wypełniły zajęcia praktyczne i terenowe, związane między innymi ze zwiedzaniem Ośrodka Edukacji Przyrodniczo-Leśnej w Jeziorach Wysokich, Gospodarstwa Agroturystycznego w Suchodole, także z udziałem w „Jasieńskiej Wiośnie" - zorganizowanej przez koło PTTK w Jasieniu.

Wieczorem drugiego dnia konferencji odbyła się biesiada turystyczna , której ważnym punktem był występ zespołu wokalno-muzycznego żarskich „Łazików” (skupiającego wychowanków miejscowego Technikum Budowlanego i nadal czynnych turystów).

Wiestaw Jamrożek

\footnotetext{
${ }^{2} \mathrm{~W}$ konferencji wzięło udział ponad 100 uczestników. Pierwotnie udział w konferencji zapowiedzieli naukowcy z Rosji i Ukrainy.
} 